\title{
In vitro neutralizing activity of BNT162b2 mRNA-induced antibodies against full B.1.351 SARS-CoV-2 variant
}

\author{
Federico García ${ }^{1}$, Esther Serrano-Conde ${ }^{1}$, Alba Leyva ${ }^{2}$, Ana Fuentes-Lopez ${ }^{1}$, Adolfo de \\ Salazar $^{1}$, Natalia Chueca ${ }^{1}$, Sonia Pérez Castro ${ }^{3}$, Benito Regueiro ${ }^{3}$, Almudena Rojas ${ }^{2}$, \\ Joaquín Mendoza ${ }^{2}$, and Jose Rojas ${ }^{2}$ \\ ${ }^{1}$ Hospital Universitario San Cecilio \\ ${ }^{2}$ Vircell SL \\ ${ }^{3}$ Hospital Alvaro Cunqueiro
}

December 6, 2021

\begin{abstract}
Background: SARS-CoV-2 variation represents a serious challenge to current COVID-19 vaccines. Recent reports suggest that B.1.351 and other variants may escape the neutralization activity of the antibodies generated by current vaccines. Methods: Ninety-nine healthcare workers undertaking BNT162b2 mRNA vaccination were sampled at baseline, on the day of the second dose, and 14 days after the latter. Neutralization activity against SARS-CoV-2 B.1, B.1.1.7 and B.1.351 was investigated using a Vero-E6 model. Results: Eleven of the study participants had prior infection with SARS-CoV-2. Neutralization titers against the B.1 and the B.1.1.7 variants were not statistically different and were significantly higher than titers against the B.1.351 variant across pre-exposed and non-pre-exposed vaccinated individuals $(p<0.01)$. While all vaccinated individuals presented neutralizing antibodies against B.1 and B 1.1.7 after the second dose, $14 \%$ were negative against B.1.351, and $76 \%$ had low titers (1/20-1/80). Pre-exposed vaccinated individuals showed higher titers than non-pre-exposed after the first (median titers of $1 / 387$ versus $1 / 28$, respectively) and the second doses (1/995 versus $1 / 703$, respectively). As high as $72 \%$ of the pre-exposed vaccinees presented titers $>1 / 80$ after a single dose, while only $11 \%$ of non-exposed vaccinated individuals had titers $>1 / 80$. Conclusions: BNT162b2 mRNA-induced antibodies show a lower in vitro neutralizing activity against B.1.351 variant compared to neutralization against B.1.1.7 or B.1 variants. Interestingly, for individuals pre-exposed to SARS-CoV-2, one dose of BNT162b2 mRNA may be adequate to produce neutralizing antibodies against B.1.1.7 and B.1, while two doses of BNT162b2 mRNA provide optimal neutralizing antibody response against B.1.351 too.
\end{abstract}

\section{Hosted file}

Paper 22_11.docx available at https://authorea.com/users/345597/articles/548293-in-vitroneutralizing-activity-of-bnt162b2-mrna-induced-antibodies-against-full-b-1-351-sars-cov2-variant 

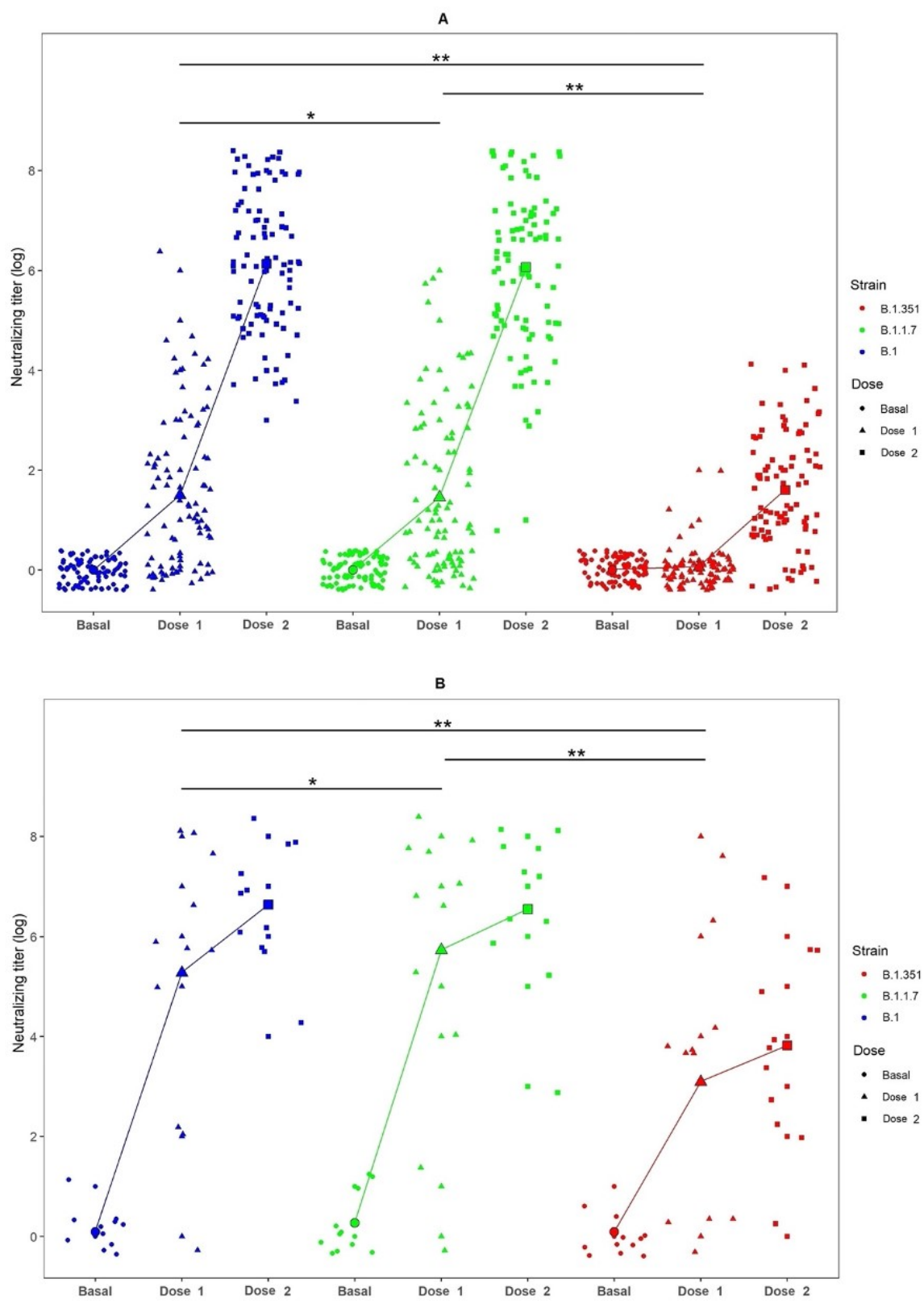

\section{Hosted file}

Table 1.docx available at https://authorea.com/users/345597/articles/548293-in-vitroneutralizing-activity-of-bnt162b2-mrna-induced-antibodies-against-full-b-1-351-sarscov-2-variant 